\title{
Mycota of distillery yeast sludge as source of single cell protein
}

\author{
Valentino MJG ${ }^{1}$, Kalaw $\mathrm{SP}^{\mathbf{1}}$, Galvez $\mathrm{CT}^{\mathbf{1}}$ and Reyes RG ${ }^{\mathbf{1}}$ \\ ${ }^{1}$ Department of Biological Sciences, College of Arts and Sciences, Central Luzon State University, Science City of \\ Munoz, Nueva Ecija, Philippines; E-mail: maryjhanevalentino@yahoo.com.ph
}

Valentino MJG, Kalaw SP, Galvez CT, Reyes RG 2015 - Mycota of distillery yeast sludge as source of single cell protein. Mycosphere 6(2), 241-247, Doi 10.5943/mycosphere/6/3/1

\begin{abstract}
This study focused on the isolation, identification, and utilization of the mycota present in distillery yeast sludge as source of single cell protein. Seven fungal isolates were described and identified. These include three species of yeasts (Saccharomyces cerevisiae Meyen ex E.C. Hansen, Candida parapsilosis (Ashford) Langeron and Talice, and Candida guilliermondii (Castellani) Langeron et Guerra) and four species of molds (Aspergillus flavus Link, Aspergillus niger van Teigh, Aspergillus japonicus Saito var japonicus, and Rhizopus sp.).

The ability of the fungal isolates to produce single cell protein was evaluated by determining the crude protein content (CPC) of the distillery yeast sludge after 14 days of solid state fermentation. Results revealed that inoculation of the seven taxa produced significantly higher percentage CPC of the distillery yeast sludge. Apparently, S. cerevisiae-treated distillery yeast sludge had the highest percentage CPC of $33.7 \%$ and the highest percentage increase in CPC of $34.3 \%$, while Rhizopus sp.-treated distillery yeast sludge had the lowest of $21.8 \%$. Thus, the present study indicates the great potential of the seven taxa as source of single cell protein using the distillery sludge as substrate.
\end{abstract}

Keywords - crude protein content - distillery yeast sludge - fermentation - mycota - single cell protein

\section{Introduction}

In the Philippines, the sugar industry is one of the country's oldest and leading export earners. Based on reports, there are about 411,100 hectares of sugarcane plantation producing million metric tons of sugar and molasses. Molasses, a byproduct of sugar, provide a substantial supply of feed materials for the livestock industry, $67 \%$ of it is exported, $17 \%$ is used by distilleries, and $16 \%$ is used for feeds (Rojas 1995).

Distillery yeast sludge (distiller's sludge) is produced as solid waste in the brewing industry. It contains a high amount of protein $(21 \%)$ and is also rich in essential amino acids such as lysine, methionine, glycine, arginine, leucine, and histidine, which are essential for the growth and health of animals (Sudha Rameshwari \& Karthikeyan 2005). Moreover, dried distillery grains are also sold as cattle feed and due to their abundant availability, it can also serve as an ideal substrate for microbial processes for the production of single cell protein.

Single cell proteins (SCP) are dried cell mass of microorganisms such as fungi, algae, and bacteria, which contain high concentration of nucleotides, inositol, and glutamic acid. It can also contain other biological molecules like lipids, carbohydrates, and vitamins. They can also be called 
as biomass, bioprotein, or microbial protein (Silva et al. 2009, Azam et al. 2014). Microorganisms are great sources of SCP due to its rapid growth rate, their ability to synthesize inexpensive substrates as carbon sources, and their high efficiency to convert carbon sources to protein (Glazer \& Nikaido 2007).

Several studies have been reported to utilize different species of yeasts and molds using various agro-industrial wastes for single cell protein production. Hence, the study has been carried out to identify the mycota present in the distillery yeast sludge and to probe their potential in single cell protein production. The results would provide baseline information on the mycota thriving in distillery yeast sludge that would lead to further utilization of these taxa as source of microbial protein using the dried distillery yeast sludge as substrate which can then be used as supplement to costly livestock feeds. It can be of significance in the Philippines where there is a surplus of carbohydrates and inadequate supply of proteins.

\section{Materials and Methods}

\section{Isolation of Mycota}

Sugarcane distillery yeast sludge was collected directly from the discarding area of the distillery tank of Azucarera de Tarlac, Tarlac City, Tarlac, Philippines. The collected distillery yeast sludge were serially diluted up to $10^{-5}$ dilution and were pour plated into the Potato Dextrose Agar (PDA), Malt Extract Yeast Agar (MYA), and Yeast Agar (YA) plates. Cultures were then incubated for 4-7 days at $28^{\circ} \mathrm{C}$ in inverted position. After which, distinct colonies of yeasts and molds were isolated, purified, and maintained in MYA (yeasts) and PDA (molds) slants for further identification.

\section{Identification of Mycota}

Identification of mold isolates was based on their cultural and morphological characteristics and was referred to the taxonomic keys by Klich \& Pitt (1988) and Lodder (1970). Meanwhile, API $\mathrm{C}$ AUX yeast identification system was employed for yeast isolates.

\section{Preparation of the Inoculum}

Inoculum was prepared by growing molds in PDA for seven days and yeasts in MYA for three days. Then, $20 \mathrm{ml}$ of sterile water was added to the cultures and adjusted to $5.0 \times 10^{6}$ cells per $\mathrm{ml}$ with sterile distilled water. Cells were counted using a hemacytometer.

\section{Preparation of the Substrate}

Dried yeast sludge was collected from Central Azucarera de Tarlac. Dried yeast sludge was analyzed for its Crude Protein Content (CPC) using Kjeldahl method. This CPC served as the initial CPC of the substrate. One hundred fifty (150) grams of dried yeast sludge was placed in a clean culture bottle and $110 \mathrm{ml}$ of water was added to the substrate to obtain $60-65 \%$ moisture content. These were covered with plastic and were sterilized at $121^{\circ} \mathrm{C}, 15 \mathrm{psi}$ for one hour.

\section{Inoculation of Mycota in Sugarcane Distillery Yeast Sludge}

Ten $\mathrm{ml}$ of the adjusted spore suspension of different mycota was aseptically transferred to the substrate. Cultures were covered with sterile cheesecloth and a sterile bamboo stick was inserted into the cheesecloth to facilitate the mixing of cultures every 72 hours to prevent the settling of the cells at the bottom of the cultures. The cultures were cultivated for 14 days at $28^{\circ} \mathrm{C}$.

\section{Harvesting and Crude Protein Analysis}

After 14 days of cultivation, the cultures were sterilized $\left(121^{\circ} \mathrm{C}, 15\right.$ psi for 1 hour $)$, air dried for 7 days, and were pulverized using mortar and pestle. Crude protein content (CPC) was analyzed using Kjeldahl method. The fungal-enriched sugarcane distillery yeast sludge CPC served as the final CPC. Whereas, the CPC of the uninoculated sugarcane distillery yeast sludge served as the 
initial CPC.

Data were analyzed using Analysis of Variance (ANOVA) and Comparison among Means by Duncan's Multiple Range Test (DMRT) at 5\% and 1\% levels of significance.

\section{Results and Discussion}

\section{Characterization and Description of Fungal Isolates}

Three species of yeasts (Figs 1A-C) namely: Saccharomyces cerevisiae Meyen ex E. C. Hansen, Candida parapsilosis (Ashford) Langeron and Talice, and Candida guilliermondii (Castellani) Langeron et Guerra) and four species of molds (Figs 1D- F ) such as Aspergillus niger van Teigh, Aspergillus japonicus Saito var japonicus, Aspergillus flavus Link, and Rhizopus species were isolated, described and identified based on the taxonomic keys by Klich \& Pitt (1988) and Lodder (1970).

\section{Saccharomyces cerevisiae Meyen ex E.C. Hansen}

Colonies of $S$. cerevisiae as observed on MYA after three days of incubation were off-white in color, circular in shape, with dull and smooth texture, convex elevation, and entire margin (Fig 1 A). For the physiological characteristics, S. cerevisiae had a positive result in D-glucose, Dgalactose, Methyl- $\alpha$-D-glucopyranoside, D-maltose, D-saccharose, D-trehalose, D-melezitose, and D-rafinose. On the other hand, it had a negative result in glycerol, L- arabinose, calcium-2-ketogluconate, L-arabinose, D-xylose, adonytol, xylitol, inositol, N-acetyl-glucosamine, D-cellobiose, and D-lactose.

\section{Candida guilliermondii (Castellani) Langeron et Guerra}

Colonies of $C$. guilliermondii grown on MYA were off-white in color and circular in shape. Colonies had a dull and smooth texture with convex elevation and margins were entire (Fig 1B). For its physiological characteristics, it had a positive result for D-glucose, glycerol, calcium-2-ketogluconate, L-arabinose, D-xylose, adonitol, xylitol, D-galactose, D-sorbitol, Methyl- $\alpha$-Dglucopyranoside, N-acetyl-glucosamine, D-cellobiose, D-maltose, D-saccharose, D-trehalose, Dmelezitose, and D- raffinose. Meanwhile, it had a negative result for inositol and D-lactose substrate.

\section{Candida parapsilosis (Ashford) Langeron and Talice}

The colonies of $C$. parapsilosis grown on MYA were off-white in color, circular in shape, had dull and smooth texture and with convex elevation and with entire margin (Fig 1C). $C$. parapsilosis had a positive result for D-glucose, glycerol, calcium-2-keto-gluconate, L-arabinose, D-xylose, D-galactose, D-sorbitol, Methyl- $\alpha$-D-glucopyranoside, N-acetyl-glucosamine, Dmaltose, D-galactose, D-cellobiose, D-saccharose, D-melezitose and negative for adonitol, xylitol, inositol, D-trehalose, and D-raffinose.

\section{Aspergillus japonicus Saito var japonicus}

Aspergillus japonicus colonies on PDA were initially white, and became light to dark brown in color and the mycelium was floccose and sporulating densely (Fig 1D). The conidial head of A. japonicus was spherical to radiate in shape, splitting into well-defined divergent columns as it aged and was colored black. Its conidiophores were long, smooth-walled, hyaline, and slightly pigmented at the apex. From the conidiophores were the brown and subspherical vesicles. Then covering the vesicles was a single row of phialides where the conidia were borne. The conidia were hyaline to brown in color with subspherical to ellipsoidal shape. Hyphae were septated and hyaline.

\section{Aspergillus flavus Link}

Aspergillus flavus colonies on PDA were initially white, turning yellowish green to green in color as it matured (Fig 1E). Conidial heads of A. flavus were radiate to loosely columnar in 
shape. The conidiophores were coarsely roughened and hyaline. Arising from the conidiophores were the globose to sub-globose vesicles. Then covering the entire vesicles was the metulae from where the phialides were borne. Conidia of A. flavus were globose to subglobose in shape with smooth to very finely roughened texture. The hyphae were septated and hyaline.

\section{Aspergillus niger van Teigh}

Aspergillus niger grown on PDA were initially white, quickly becoming black with the formation of its conidia. Conidial heads were radiate (Fig 1F) which split into columns during maturity. Their conidiophores were long, smooth in texture, and hyaline in color and became darker at the apex. From the apex of the conidiophores were the pale-brown and globose vesicles. Covering the entire vesicles of $A$. niger were the brown metulae which in turn gave rise to the phialides. Borne from the phialides were brown and globose conidia.

\section{Rhizopus sp.}

Rhizopus sp. on PDA were initially white turning grayish black and grew very rapidly (Fig $1 G)$. Sporangiophores, rhizoids, sporangia, collumelae, and sporangiospores were visualized for the morphological characteristics of the Rhizopus sp. Its sporangiophores were long and brown in color. At the lower end part of the sporangiophores were the rhizoids and at the tip of the sporangiophores were the sporangia which were round in shape with flattened base. Collumelae with a hemispherical shape were also present. Borne from the sporangia and collapsed collumelae were the sporangiospores. Sporangiospores were unicellular, round to ovoid in shape, hyaline to brown in color, and smooth in texture. In addition, the hyphae of Rhizopus sp. were broad and nonseptated.

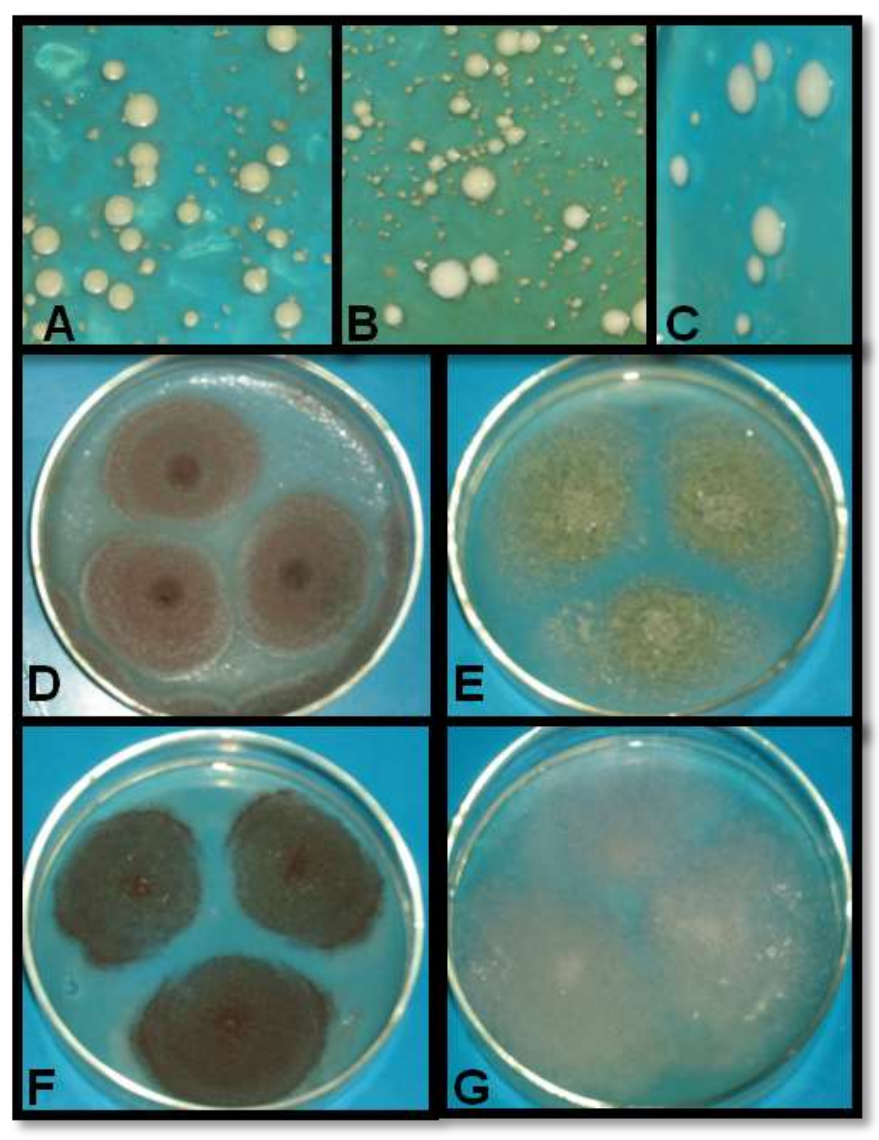

Fig. 1 - Cultural features of (A) S. cerevisiae (B) C. guilliermondii (C) C. parapsilosis on MYA after 3 days of incubation; (D) A. japonicus (E) A. flavus (F) A. niger (G) Rhizopus sp. on PDA after 7 days of incubation against blue background 


\section{Crude Protein Content (CPC) Profile of the Dried Distillery Yeast Sludge}

Evaluation of the CPC of the fungal-enriched distillery yeast sludge was made through Kjeldahl method. The gross percentage CPC of the distillery yeast sludge are shown in Table 1 . Interestingly, inoculation of fungal isolates increased the gross CPC of the distillery yeast sludge, which were significantly higher than the uninoculated sludge. S. cerevisiae-treated distillery yeast sludge registered the highest percentage mean of $33.7 \%$, followed by A. niger-treated sludge and C. guilliermondii-treated sludge with means of $32.5 \%$ and $32.2 \%$, respectively. Meanwhile, the uninoculated-distillery sludge had the least percentage CPC of $25.1 \%$. Statistical analysis for the gross percentage CPC of distillery yeast sludge suggests that there is a highly significant difference among the treatment means. These indicate that the inoculation of the seven mycota affected the percentage CPC of the distillery yeast sludge thus increasing the CPC of the distillery yeast sludge and were significantly higher compared to the untreated yeast sludge. Similarly, Humdy (2013) reported the efficiency of $A$. niger, $R$. oryzae, and $S$. cerevisiae in SCP production wherein profiles of essential amino acids are comparable with FAO standards. While El-Deek et al. (2009) demonstrated the superior ability of different strains of yeast including Candida utilis, C. tropicalis, Saccharomyces cerevisae, S. uvarum, and Rhodotorula rubra to hydrolyze uric acid and produce protein when grown on dried poultry manure medium.

Results of the present study confirm the reports of Nasseri (2011) that several species of filamentous fungi such as Aspergillus, Chaetomium, Paecilomyces, Penicillium, Trichoderma, and yeasts including Candida, Kluyveromyces, and Saccharomyces, are SCP producers. This also coincides with Bacha et al. (2011), wherein Saccharomyces cerevisiea is considered the most vital source of single cell protein because of its easy harvesting, larger cell size with lower content of nucleic acids, and bioactive mixture of essential amino acids. Furthermore, Beningson (1992) \& Pandey (1994) also revealed that most species of Aspergillus and Rhizopus produce carbohydratehydrolyzing enzymes in the likes of cellulases, xylanases, pectinases, $\alpha$-amylase, glucoamylases, glucanases, lipases, hemicellulases, and proteases.

Table 1 Gross percentage CPC of distillery yeast sludge

\begin{tabular}{lc}
\hline \multicolumn{1}{c}{ Treatment } & Mean percentage crude protein \\
\hline A. niger -treated distillery sludge & $32.5^{\mathrm{b}}$ \\
A. japonicus -treated distillery yeast sludge & $30.7^{\mathrm{c}}$ \\
A. flavus - treated distillery sludge & $30.9^{\mathrm{c}}$ \\
Rhizopus- treated distillery sludge & $30.5^{\mathrm{c}}$ \\
C. guillermondii- treated distillery sludge & $32.2^{\mathrm{b}}$ \\
C. parapsilosis- treated distillery sludge & $31.2^{\mathrm{c}}$ \\
S. cerevisiae- treated distillery sludge & $33.7^{\mathrm{a}}$ \\
Control- uninoculated distillery sludge & $25.1^{\mathrm{d}}$ \\
\hline
\end{tabular}

*Treatment means with the same letter are not significantly different at 0.01 level of significance

\section{Percentage Increase in Crude Protein Content of the Distillery Yeast Sludge}

Percentage increase in crude protein content of the distillery yeast sludge is presented in Table 2. S. cerevisiae-treated distillery yeast sludge registered the highest percentage increase in CPC of $34.3 \%$, followed by A. niger-treated distillery yeast sludge, and C. guilliermondii-treated distillery yeast sludge with means of $29.6 \%$ and $28.6 \%$, respectively. Rhizopus sp.-treated distillery yeast sludge obtained the lowest CPC of $21.8 \%$. Among the seven isolated mycoflora, S. cerevisiae increased the percentage in CPC of the distillery yeast sludge which is significantly higher compared to the six fungal isolates. This implies greater ability of $S$. cerevisiae in the production of single cell protein. According to Davies (1994) S. cerevisiae can provide proteins, carbohydrates, fats, vitamins (mainly the B group), minerals, essential amino acids including lysine, which is generally higher than in bacteria, algae, and molds. Moreover, Ingram (2002) mentioned that $S$. cerevisiae also contains thiamine, tryptophan, riboflavin, biotin, niacin, pantothenic acid, pyridoxine, choline, streptogenin, glutathione, lysine, folic acid, and P-amino benzoic that contribute to its single cell protein production capability. 
Table 2 Mean percentage increase in CPC of fungal-enriched distillery yeast sludge after 14 days of incubation

\begin{tabular}{lc}
\hline \multicolumn{1}{c}{ Treatment } & Percentage increase in CPC \\
\hline A. niger -treated distillery sludge & $29.6^{\mathrm{b}}$ \\
A. japonicus -treated distillery yeast sludge & $22.5^{\mathrm{c}}$ \\
A. flavus - treated distillery sludge & $23.4^{\mathrm{c}}$ \\
Rhizopus- treated distillery sludge & $21.8^{\mathrm{c}}$ \\
C. guillermondii- treated distillery sludge & $28.6^{\mathrm{b}}$ \\
C. parapsilosis- treated distillery sludge & $24.3^{\mathrm{c}}$ \\
S. cerevisiae- treated distillery sludge & $34.3^{\mathrm{a}}$ \\
\hline
\end{tabular}

* Treatment means with the same letter are not significantly different at 0.01 level of significance

As indicated in this study among the species of molds, A. niger has the highest percentage increase in CPC. This result corresponds to that of Yigitoglu (1992), who found out that A. niger was superior to other species of Aspergillus and strains of fungi in biomass yield from agricultural waste. In addition, Ikenebomeh \& Chikwendu (1997) observed high amylolytic activity of $A$. niger in biomass production while its ability to produce strong activity in beta glucosydase resulting to deglycosylation of the substrate was accounted by Rashid et al. (1997) and Suto \& Tomita (2001). Moreover, single cell protein product obtained from A. niger contained $30.4 \%$ crude protein and had an essential amino acid profile featuring high lysine content and appreciable amounts of methionine and tryptophan (Singh et al. 1991). Thus, the superiority of A. niger among the species of molds was established.

In the present study, the great ability of the seven mycota present in the distillery yeast sludge to produce single cell protein was clearly demonstrated thus increasing the CPC of the yeast sludge. It also indicates the potentiality of the sugarcane distillery yeast sludge as carbon source for SCP production.

\section{Acknowledgement}

The authors would like to thank the Department of Biological Sciences, College of Arts and Sciences, CLSU for providing laboratory facilities during the conduct of the study.

To God be the glory. Thy will be done.

\section{References}

Azam S, Zeeshan K, Bashir A, Khan I, Ali J. 2014 - Production of Single Cell Protein from Orange Peels Using Aspergillus niger and Saccharomyces cerevisiae. Global Journal of Biotechnology \& Biochemistry 9 (1), 14-18.

Association of Analytical Chemist. 1980 - Official Methods of Analysis. $15^{\text {th }}$ edition. Association of Official Analytical Chemist. Arlington, Virginia, USA.

Bacha U, Nasir M, Khalique A, Anjum AA, Jabbar MA. 2011 - Comparative assessment of various agroindustrial wastes for Saccharomyces cerevisiae biomass production and its quality evaluation as single cell protein. The Journal of Animal \& Plant Sciences 21(4), 844-849.

Beningson HE. 1992 - Development of free-flowing powder fuels from biomass. fuels and feedstocks from tropical biomass II. San Juan, Puerto Rico.

Davies RW. 1994 - Heterologous gene expression and protein secretion in Aspergillus. Progress in Industrial Microbiology 29, 527-60.

El-Deek AA, Ghonem KM, Hamdy SM, Aser MA, Aljassas FH, Osman MM. 2009 - Producing single cell protein from poultry manure and evaluation for broiler chickens diets. International Journal of Poultry Science 8 (11), 1062-1077.

Glazer AG, Nikaido H. 2007 - Microbial Biotechnology: Fundamentals of Applied Microbiology: $2^{\text {nd }}$ Edition. Cambridge University Press, Cambridge. 
Humdy H. 2013 - Production of mini-food by Aspergillus niger, Rhizopus oryzae and Saccharomyces cerevisiae using orange peels. Romanian Biotechnological Letters 18 (1), 7929-7946.

Ikenebomeh MJ, Chikwendu AE. 1997 - Aspergillus niger biomass production in cassava whey medium. Nigerian Journal of Microbiology 11, 52-63.

Ingram S. 2002 - The real nutritional value of fungi. United Kingdom: Cancer Research UK.

Klich MA, Pitt JI. 1988 - The deuteromytes mitosporic fungi classification and generic keys. USA. Science Publishers. Inc.

Lodder J. 1970 - The Yeasts. A taxonomic study. Amsterdam Holland, North Holland, Publishing Company.

Nasseri AT, Rasoul-Amii S, Moramvat MH, Ghasemi Y. 2011 - Single cell protein: Production and process. American Journal of Food Technology 6(2), 103-116.

Pandey A. 1994 - Solid state fermentation (ed. Pandey, A.). New Delhi. Wiley Eastern Publishers, New Delhi.

Pandey A and Soccol CR. 1998 - Bioconversion of biomass: A case study of ligno-cellulosics bioconversions in solid state fermentation. Brazilian Archive of Biology and Technology 41 (4), 379-390.

Rashid MH, Rajoka MI, Siddiqui KS, Shakoori AR. 1997 - Kinetic Properties of Chemically Modified Beta Glucosidase from A. niger 280. Pakistan Journal of Zoology 29, 354-363.

Rojas DB. 1995 - Sugarcane and its by-products for animal feed. Animal Production Technology 1. University of the Philippines, Los Baños, Laguna, Philippines.

Silva VK, Della Torre da Silva J, de Faria Filho DE, Hirota Hada F, Barbosa de Moraes VM. 2009 -Humoral immune response of broilers fed diets containing yeast extract and prebiotics in the prestarter phase and raised at different temperatures. Journal of Applied Poultry Researches 18, 530-540.

Singh A, Abidi AB, Agrawal K, Darmwal NS. 1991 - Single cell protein production by Aspergillus niger and its evaluation. Zentralbl-Mikrobiol Journal, 146 (3), 181-184.

Sudha Rameshwari K, Karthikeyan S. 2005 - Distillery Yeast Sludge (DYS) as an Alternative Feed Resource in Poultry. International Journal of Poultry Science 4 (10), 787-789.

Suto M, Tomita F. 2001 - Induction and catabolite repression mechanisms of cellulose in fungi. Journal of Bioscience Bioengineering 92, 305-311.

Yigituglo M. 1992 - Production of citric acid by fungi. Journal of Islamic Academy of Sciences 5(2), 100-106. 